[DOI: 10.24214/jecet.A.9.3.47180.]

Jaurnal of Environmental Science, Computer Science and Engineering \& Technology

An International Peer Review E-3 Journal of Sciences and Technology

Available online at www.jecet.org

Section A: Environmental Science

Research Article

\title{
Physicochemical Characteristics, Heavy Metal Levels and Pollution Index Status in Soil Samples around Nnobi Abattoir in Anambra State.
}

\author{
${ }^{1}$ Okeke O., ${ }^{2}$ Ndubuisi J. O., ${ }^{3}$ Ozuah A. C., ${ }^{4}$ Aniobi C.C. and ${ }^{5}$ Okeke M.U. \\ 1 Plastic Production Section, Scientific Equipment Development Institute, Enugu. \\ ${ }^{2}$ Applied Science Department, Federal College of Dental Technology and Therapy,Enugu. \\ ${ }^{3}$ Integrated Science Department, Nwafor-Orizu College of Education, Nsugbe. \\ ${ }^{4}$ Department of Community Medicine, University of Nigeria, Enugu Campus. \\ ${ }^{5}$ Science Laboratory Technology (Chemistry Option), Federal College of \\ Agriculture, Ishiagu, Ebonyi State.
}

Received:13 June 2020; Revised: 22 June 2020; Accepted: 30 June 2020

\begin{abstract}
Physicochemical parameters ( $\mathrm{pH}$, electrical conductivity, total organic carbon, organic matter, sulphate and phosphate) and heavy metals (copper, lead and chromium) were determined in the soils around the abattoir in Nnobi, Idemmili South Local Government Area in Anambra State, using standard analytical procedures and instrumentation. The physicochemical properties of the soil samples were determined using established analytical procedures while the levels of the heavy metals were determined using atomic absorption spectrophotometer. The soil samples $\mathrm{D}_{1-4}$ and control had mean range of values of $6.43-7.22,0.85-5.84 \%, 32.20-41.16 \mu \mathrm{S} / \mathrm{cm}$, $23.05-30.14 \mathrm{mg} / \mathrm{l}, 2.13-4.66 \mathrm{mg} / \mathrm{l}$ and $4.83-8.91 \%$ for $\mathrm{pH}$, total organic carbon, electrical conductivity, sulphate, phosphate and organic matter content respectively. The soil samples $D_{1-4}$ and control had mean range of values of 28.61-18.64, 0.58$0.26,0.98-0.74 \mu \mathrm{g} / \mathrm{g}$ for $\mathrm{Cu}, \mathrm{Pb}$ and $\mathrm{Cr}$ respectively. The levels of the studied physicochemical parameters and heavy metals in the soil sampling points $\mathrm{D}_{1-4}$ and control were all statistically significant. Of all the studied parameters, only the mean
\end{abstract}


levels of total organic carbon and $\mathrm{Pb}$ in soil sampling point $\mathrm{D}_{1}$ exceeded the WHO threshold limits. The proximity of sampling points $D_{1-3}$ from the abattoir, where the effluent discharge occurs, significantly increased its acidic values, thus consequently resulting in higher mean values for all the studied physicochemical parameters and heavy metals than in sampling point $\mathrm{D}_{4}$ and control. The pollution index result indicated that the soil samples had slight to severe contamination status with $\mathrm{Cu}$ and $\mathrm{Cr}$ except $\mathrm{Pb}$ in soil sampling point $\mathrm{D}_{1}$ that had slight pollution status. If the pollution index status of especially soil sampling point $D_{1}$ is sustained as a result of the abattoir effluent discharge, the impact on the environment could be of public health emergency.

Key words: Physicochemical parameters, Abattoir effluents, Heavy metals, Pollution index and soils.

\section{INTRODUCTION}

Research has shown that environmental pollution and its attendant impacts on land, air and water qualities are more severe now than before ${ }^{1}$. The major cause of environmental pollution is the indiscriminate discharge of wastes into the natural environment thereby tampering and negatively altering the natural qualities of the major components of the environment. Different pollutants are discharged into the environment through anthropogenic (agricultural and industrial) activities and natural sources ${ }^{2}$.

Pollutants discharged into the environment often come in the form of wastes from the relevant pollution sources ${ }^{3}$. Adesemoye et al. ${ }^{4}$ reported that in many parts of the world, human activities which includes rearing of animals and processing of meat has negative consequences on the soil and in the general environment. The ceaseless resolve to advance the production of meat in order to satisfy the nutritional requirements of the populace is often related with some challenges of air, water, food and soil pollution ${ }^{5}$.

An abattoir is a specialized environment where animals are slaughtered and processed for their meat. These premises are duly approved and registered by government regulatory agencies so that the slaughtering of animals can be done with the utmost hygiene and also proper inspection can be carried out during the processing, preservation and storage of the meat for human consumption ${ }^{6}$.

According to Olanike, ${ }^{7}$ the disposal of the waste generated from slaughter houses are done without consideration to legislative conditions or principles. Globally, abattoirs are directly or indirectly identified as a source of environmental pollution through a number of its numerous operational processes ${ }^{8}$.

In Nigeria, abattoir activities are operated by butchers who have little or no idea of sanitary principles. These activities are usually accompanied by the generation of large amounts of organic and inorganic wastes which are usually discharged on the soil and in water bodies around the abattoir premises. Additional reports have been reported on the effect of abattoir wastes on the soil which were enumerated to include increase in concentration of trace and heavy metals, increase in population of decomposers, loss of aesthetic value, excessive soil nutrient and increase in accumulation of organic toxins ${ }^{9}$.

The existence and perverseness of toxic metals in the soil are dangerous to the microbes in the soil as well as the plants. Different body parts of livestock such as the flesh, blood, liver, kidney, innards and hairs have been discovered to consist of heavy metals, as well as altering the $\mathrm{pH}$ of the soil ${ }^{10}$. The 
resultant effect is that crops grown on such polluted soils exhibits a decrease in development and yield. The soil is a natural sink and therefore receives as much quantity of organic and inorganic pollutants as possible ${ }^{11}$.

According to Sharma et al. ${ }^{12}$, the deposition of metallic ions in the soil is known to influence the physicochemical properties, mobilization, release, sorption and adsorption characteristics of the soil. The quantity of heavy metals introduced into the soil will increase the concentration of both essential and non-essential metals in the soil and also affect the physical and chemical properties of the soil ${ }^{13}$.

Heavy metal contamination of top soils has been a major concern regarding their toxicity, persistence and non-biodegradability in the environment. Effect of elevated concentrations of heavy metals to soil functions, soil microbial composition and growth have long been reported under both field and laboratory conditions ${ }^{14}$.

Toxicities of heavy metals such as $\mathrm{Pb}, \mathrm{Cd}, \mathrm{Hg}, \mathrm{As}, \mathrm{Cr}$ and $\mathrm{Ag}$ have been reported extensively ${ }^{15}$. Dietary intake of contaminated food crops results in long term accumulation of heavy metals and the detrimental impact becomes apparent only after several years of exposure. This research therefore assessed the physicochemical parameters, heavy metal levels and pollution index status in soil samples around Nnobi abattoir in Anambra State with a view to determining the impact of these abattoir effluents discharge on the environment.

\section{MATERIALS AND METHODS}

Sample location and collection: Soil samples were collected from the abattoir located in Nnobi, Idemmili South local government area in Anambra State. The abattoir is a very big one with an average slaughter of 10 cows and 7 goats on daily basis ${ }^{5}$. Soil samples $(0-15 \mathrm{~cm})$ were collected at distances of 3, 6, 9 and $12 \mathrm{~m}$ from the abattoir and were denoted as $D_{1}, D_{2}, D_{3}$ and $D_{4}$ respectively. Soil samples were collected from a distance of $100 \mathrm{~m}$ away from the abattoir, where no such activities takes place and was called the control sample. Five composite soil samples each were collected from sampling points $\mathrm{D}_{1}, \mathrm{D}_{2}, \mathrm{D}_{3}$ and $\mathrm{D}_{4}$ and control. The soil samples were packed in clean labeled polyethene bags and transported to the laboratory for analysis.

Determination of the physicochemical parameters : The physicochemical parameters of the soil samples were obtained by applying the standard methods for analysis of soils as described by $\mathrm{AOAC}^{16}$, Udo and Ogunwale ${ }^{17}$. The physicochemical parameters determined were $\mathrm{pH}$, total organic carbon, electrical conductivity, sulphate, phosphate and organic matter content.

Determination of heavy metals : The soil samples were ground, sieved and digested with $10 \mathrm{ml}$ of aqua regia $\left(\mathrm{HCl} / \mathrm{HNO}_{3}, 3: 1\right)$. The digest were analyzed for $\mathrm{Cu}, \mathrm{Pb}$ and $\mathrm{Cr}$ using atomic absorption spectrophotometer, Perkin-Elmer, 2008 model and fitted with deuterium lamp for background correction. All regents used in this study were of pure analytical grade and were checked for possible trace metal contamination. Quality control was assured by the use of triplicates standard reference materials and procedural blanks.

Contamination/pollution (C/P) index of the metals: The contamination/pollution $(\mathrm{C} / \mathrm{P})$ index of the metals in the soil samples was calculated using the Scheme formulated by Lacatusu ${ }^{18}$. A contamination/pollution index value greater than I defines pollution range while a value less than I defines contamination range. 
Statistical Analysis : The data obtained were expressed in means and standard deviation and subjected to one way analysis of variance (ANOVA) using SPSS version 22.0 at 5\% level of confidence.

\section{RESULTS AND DISCUSSION}

Table 1: Physicochemical parameters of soil samples around Nnobi abattoir in Anambra State

\begin{tabular}{|l|c|c|c|c|c|c|c|}
\hline \multicolumn{1}{|c|}{$\begin{array}{c}\text { Sampling } \\
\text { Points } \\
\begin{array}{l}\text { Physico- } \\
\text { chemical } \\
\text { Parameters }\end{array}\end{array}$} & \multicolumn{1}{|c|}{$\mathrm{D}_{1}$} & $\mathrm{D}_{2}$ & $\mathrm{D}_{3}$ & $\mathrm{D}_{4}$ & \multicolumn{1}{c|}{ Control } & $\begin{array}{c}\text { F test } \\
\mathrm{p} \text { value }\end{array}$ & $\begin{array}{c}\text { WHO } \\
\text { STD }\end{array}$ \\
\hline $\mathrm{pH}$ & $6.43 \pm 0.11$ & $6.78 \pm 0.08$ & $6.97 \pm 0.24$ & $7.14 \pm 0.13$ & $7.22 \pm 0.16$ & 0.03 & $6.5-8.5$ \\
\hline TOC $(\%)$ & $5.84 \pm 0.36$ & $3.92 \pm 0.21$ & $3.03 \pm 0.09$ & $1.84 \pm 0.15$ & $10.85 \pm 0.11$ & 0.01 & 50 \\
\hline $\begin{array}{l}\text { Electrical } \\
\text { conductivity } \\
(\mu \text { S/cm })\end{array}$ & $41.16 \pm 0.28$ & $38.84 \pm 0.17$ & $37.06 \pm 0.06$ & $34.92 \pm 0.73$ & $32.20 \pm 0.16$ & 0.02 & 100 \\
\hline Sulphate $(\mathrm{mg} / \mathrm{l})$ & $30.14 \pm 0.10$ & $27.82 \pm 0.23$ & $26.04 \pm 0.17$ & $24.85 \pm 0.35$ & $23.05 \pm 0.23$ & 0.03 & 100 \\
\hline Phosphate $(\mathrm{mg} / \mathrm{l})$ & $4.66 \pm 0.09$ & $3.80 \pm 0.05$ & $3.17 \pm 0.20$ & $2.81 \pm 0.24$ & $2.13 \pm 0.19$ & 0.02 & 50 \\
\hline OM $(\%)$ & $8.91 \pm 0.37$ & $7.22 \pm 0.16$ & $6.94 \pm 0.13$ & $6.28 \pm 0.24$ & $4.83 \pm 0.11$ & 0.02 & 50 \\
\hline
\end{tabular}

$\mathrm{pH}$ : Result of Table 1 shows that the mean $\mathrm{pH}$ values of sampling points $\mathrm{D}_{1}, \mathrm{D}_{2}, \mathrm{D}_{3}, \mathrm{D}_{4}$ and control were $6.43 \pm 0.11,6.78 \pm 0.08,6.97 \pm 0.24,7.14 \pm 0.13$ and $7.22 \pm 0.16$ respectively. The sampling points had mean $\mathrm{pH}$ values in the following decreasing order: $\mathrm{D}_{1}>\mathrm{D}_{2}>\mathrm{D}_{3}>\mathrm{D}_{4}>$ control.

The mean levels of $\mathrm{pH}$ in the soil sampling points $\mathrm{D}_{1-4}$ and control were statistical significant. The mean $\mathrm{pH}$ value of sampling point $\mathrm{D}_{1}$ did not meet the WHO recommended permissible limits ${ }^{19}$. The result of Table 1 on $\mathrm{pH}$ shows that the soil samples became less acidic as its distance from the abattoir increases.

Therefore the most acidic of the soil samples was sampling point $\mathrm{D}_{1}$ while the less acidic was the control. According to Dan et al. ${ }^{1}$, soil $\mathrm{pH}$ plays a great role in determining nutrients availability and species of micro-organisms in the soil. Low mean $\mathrm{pH}$ values observed for the sampling points $\mathrm{D}_{1^{-} 4}$ could be as a result of decomposition of organic matter that releases carbon IV oxide which reacts with water to form carbonic acid which eventually reduces soil $\mathrm{pH}$. According to Okon et al. ${ }^{20}$ these low $\mathrm{pH}$ values enhances the solubility and mobility of heavy metals in the soil and the presence of humic acid which is the major acid in soil organic matter.

Total organic carbon (TOC):Result of Table 1 shows that mean values of total organic carbon in the sampling points $\mathrm{D}_{1}, \mathrm{D}_{2}, \mathrm{D}_{3}, \mathrm{D}_{4}$, and control were $5.84 \pm 0.36,3.92 \pm 0.21,3.03 \pm 0.09,1.84 \pm 0.15$ and $10.85 \pm 0.11 \%$ respectively. The mean TOC values of the soil samples and control differed significantly. The soil samples had mean TOC values in the following decreasing order $D_{1}>D_{2}>D_{3}>$ $\mathrm{D}_{4}>$ control. The result of this study on TOC was in agreement with the findings of Oyedele et al. ${ }^{21}$ who stated that polluted sites usually have higher organic matter and organic carbon contents compared to the control site. Although sampling point $\mathrm{D}_{1}$ had mean TOC value above the WHO recommended permissible limits, sampling points $\mathrm{D}_{2}-4$ had values which were of concern according 
to the findings of Ayolagha and Onugbuja ${ }^{22}$ who stated that organic carbon contents of soils greater than $1.2 \%$ creates conducive medium for heavy metal chelation formation. Therefore, sites with relatively high soil organic carbon could have higher concentration of heavy metals. Organic carbon content in the soil plays a vital role in the soil development, fertility and moisture availability.

Electrical conductivity (EC):Results of Table 1 shows that the mean values of electrical conductivity of sampling points $\mathrm{D}_{1}, \mathrm{D}_{2}, \mathrm{D}_{3}, \mathrm{D}_{4}$, and control were $41.16 \pm 0.28,38.84 \pm 0.17,37.06 \pm 0.06$, $34.92 \pm 0.73$ and $32.20 \pm 0.16 \mu \mathrm{S} / \mathrm{cm}$ respectively. The samples had mean electrical conductivity values in the following decreasing order: $D_{1}>D_{2}>D_{3}>D_{4}>$ control. The mean electrical conductivity values of the sampling points $\mathrm{D}_{1-4}$ and control met the WHO recommended permissible limits.

Elemile et al. ${ }^{23}$ reported higher mean electrical conductivity values of $79.60 \pm 4.2$ and $55.43 \pm 4.94$ $\mu \mathrm{S} / \mathrm{cm}$ for soils around the abattoir in Omu - Aran, Kwara State than what was obtained for EC in the studied soil samples. Accordingly, they stated that the increase in electrical conductivity in the soils around abattoirs could be due to the build-up of wastes such as bones, hairs, flesh and blood in abattoir effluents. The mean values of electrical conductivity of sampling point $\mathrm{D}_{1-4}$ and control were statistically significant.

Sulphate: Result of Table 1 shows that the mean values of sulphate in the sampling points $D_{1}, D_{2}, D_{3}$, $\mathrm{D}_{4}$, and control were $30.14 \pm 0.10,27.82 \pm 0.23,26.04 \pm 0.17,24.85 \pm 0.35$ and $23.05 \pm 0.23 \mathrm{mg} / \mathrm{l}$ respectively. The mean values of sulphate in the soil samples met WHO recommended permissible limits. The mean values of sulphate in the soil sampling points $\mathrm{D}_{1^{-}} 4$ and control differed significantly at $\mathrm{p}<0.05$. This could be attributed to the reduction in the quantity of animal wastes on the soil as the distance of the soil sampling points from the abattoir increases. The soil samples had mean values of sulphate in the following decreasing order: $D_{1}>D_{2}>D_{3}>D_{4}>$ control.According to Chukwu and Anuchi,${ }^{10}$ high values of sulphate found at the vicinity of abattoirs could be attributed to increased microbial activities due to large deposits of animal wastes.

Phosphate: Result of Table 1 shows that the mean values of phosphate in soil sampling points $D_{1}$, $\mathrm{D}_{2}, \mathrm{D}_{3}, \mathrm{D}_{4}$ and control were $4.66 \pm 0.09,3.80 \pm 0.05,3.17 \pm 0.20,2.81 \pm 0.24$ and $2.13 \pm 0.19 \mathrm{mg} / \mathrm{l}$ respectively. The mean values of phosphate in the soil samples $\mathrm{D}_{1^{-}} 4$ and control were statistically significant. The soil samples had mean values of phosphate in the following decreasing order: $\mathrm{D}_{1}>$ $D_{2}>D_{3}>D_{4}>$ control. The mean values of phosphate in the soil samples were within WHO recommended permissible limits.

Elemile et al. ${ }^{23}$ stated that if the concentration of phosphorus in the soil exceeds the acceptable limits, it could lead to the under development of plants growth and equally restricts the uptake of nitrogen by plants.

Organic matter content: The mean values of organic content in Table 1 for sampling points $\mathrm{D}_{1}, \mathrm{D}_{2}$, $\mathrm{D}_{3}, \quad \mathrm{D}_{4} . \quad$ and control were $8.91 \pm 0.37, \quad 7.22 \pm 0.16, \quad 6.94 \pm 0.13, \quad 6.28 \pm 0.24$ and $4.83 \pm 0.11 \%$ respectively.The mean values of the organic matter content in the soil samples were statistically significant. The soil samples had mean values of organic matter content in the following decreasing order:

$D_{1}>D_{2}>D_{3}>D_{4}>$ control.

The result further indicates that the mean values of organic matter content in sampling points $\mathrm{D}_{1}-4$ were higher than the values at the control and this was attributed to the lower levels of biodegradable wastes at the control site than the studied abattoir soils, suggesting therefore that waste materials from the abattoir could have significantly increased the organic matter content in the soil samples $\mathrm{D}_{1-4}$ than the control. According to Dan et al. ${ }^{1}$, soil organic matter usually acts as a store house or reservoir for 
most metals hence can influence their availability in the soil. Dan et al. ${ }^{1}$ reported a comparable mean organic matter content in the soils around abattoirs in Ikot-Ekpene in Akwa-Ibom State with that obtained in the soil samples of this research

Table 2: Heavy metal levels in the soil samples around Nnobi abattoir in Anambra State.

\begin{tabular}{|c|c|c|c|c|c|c|c|}
\hline $\begin{array}{l}\text { Sampling } \\
\text { points } \\
\text { Heavy } \\
\text { Metals }\end{array}$ & $\mathrm{D}_{1}$ & $\mathrm{D}_{2}$ & $\mathrm{D}_{3}$ & $\mathrm{D}_{4}$ & Control & $\begin{array}{l}\text { F test } \\
\mathrm{p} \\
\text { value }\end{array}$ & $\begin{array}{l}\text { WHO } \\
\text { STD }\end{array}$ \\
\hline $\mathrm{Cu}$ & $28.61 \pm 0.25$ & $24.09 \pm 0.20$ & $22.69 \pm 0.09$ & $21.11 \pm 0.17$ & $18.64 \pm 0.37$ & 0.01 & 100 \\
\hline $\mathrm{Pb}$ & $0.58 \pm 0.14$ & $0.43 \pm 0.08$ & $0.38 \pm 0.05$ & $0.31 \pm 0.08$ & $0.26 \pm 0.04$ & 0.01 & 0.5 \\
\hline $\mathrm{Cr}$ & $0.98 \pm 0.19$ & $0.86 \pm 0.10$ & $0.77 \pm 0.15$ & $0.63 \pm 0.09$ & $0.74 \pm 0.10$ & 0.03 & 10 \\
\hline
\end{tabular}

Copper: The result of Table 2 shows that the mean $\mathrm{Cu}$ levels in soil sampling points $\mathrm{D}_{1}, \mathrm{D}_{2}, \mathrm{D}_{3}, \mathrm{D}_{4}$ and control were $28.61 \pm 0.25,24.09 \pm 0.20,22.69 \pm 0.09,21.13 \pm 0.17$ and $18.64 \pm 0.37 \mu \mathrm{g} / \mathrm{g}$ respectively. The mean levels of $\mathrm{Cu}$ in the soil samples were statistically significant. The soil samples had mean values of $\mathrm{Cu}$ in the following decreasing order: $\mathrm{D}_{1}>\mathrm{D}_{2}>\mathrm{D}_{3}>\mathrm{D}_{4}>$ control.

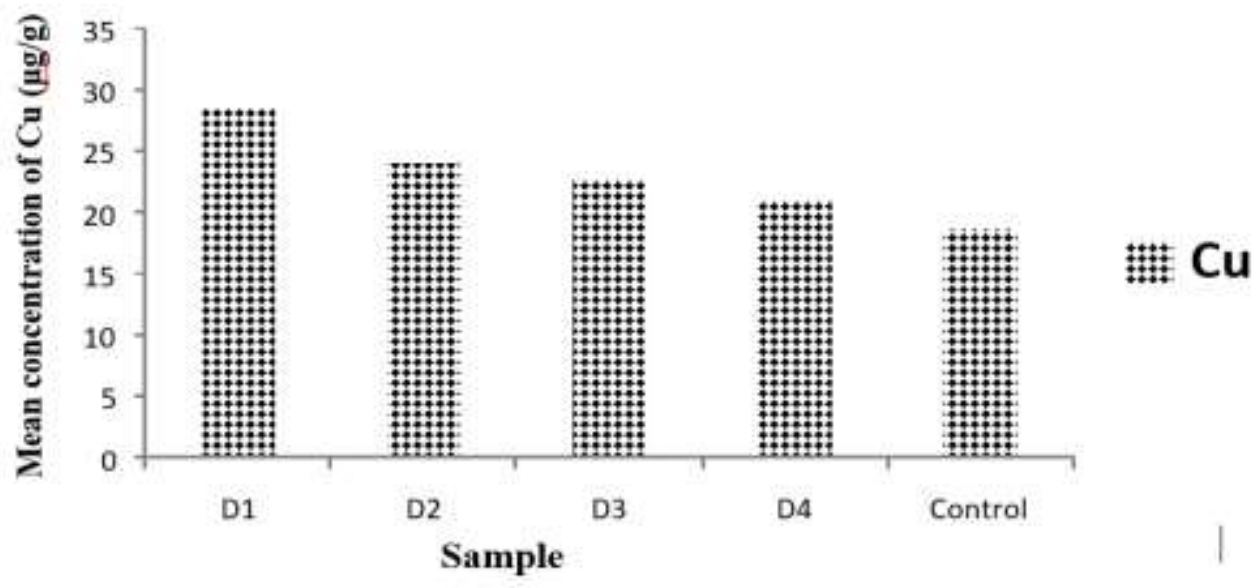

Fig. 1: Bar chart representation of the mean levels of $\mathrm{Cu}$ in the soil samples around the abattoir in Nnobi.

The mean levels of $\mathrm{Cu}$ in the soil samples were within WHO recommended limits. The result indicated that $\mathrm{Cu}$ containing wastes were more available in the soil sampling points $\mathrm{D}_{1-4}$ there at the control site. The findings of this study were consistent with the observation made by Chukwu, and Anuchi, ${ }^{10}$ on heavy metals availability around abattoir soils. Copper is an important micro nutrient which is needed for the development of both crops and animals and assist in blood synthesizing, however, at high concentration causes gastric problems, liver and kidney diseases ${ }^{24}$.

Lead: The result of Table 2 shows that the mean values of $\mathrm{Pb}$ in soil sampling points $\mathrm{D}_{1}, \mathrm{D}_{2}, \mathrm{D}_{3}, \mathrm{D}_{4}$ and control were $0.58 \pm 0.14,0.43 \pm 0.08,0.38 \pm 0.05,0.31 \pm 0.08$ and $0.26 \pm 0.04 \mu \mathrm{g} / \mathrm{g}$ respectively. The soil samples had mean values of $\mathrm{Pb}$ in the following decreasing order: $\mathrm{D}_{1}>\mathrm{D}_{2}>\mathrm{D}_{3}>\mathrm{D}_{4}>$ control. 
Except for the soil sampling point $\mathrm{D}_{1}$, all the other soil samples had mean values of $\mathrm{Pb}$ within the WHO recommended limits.

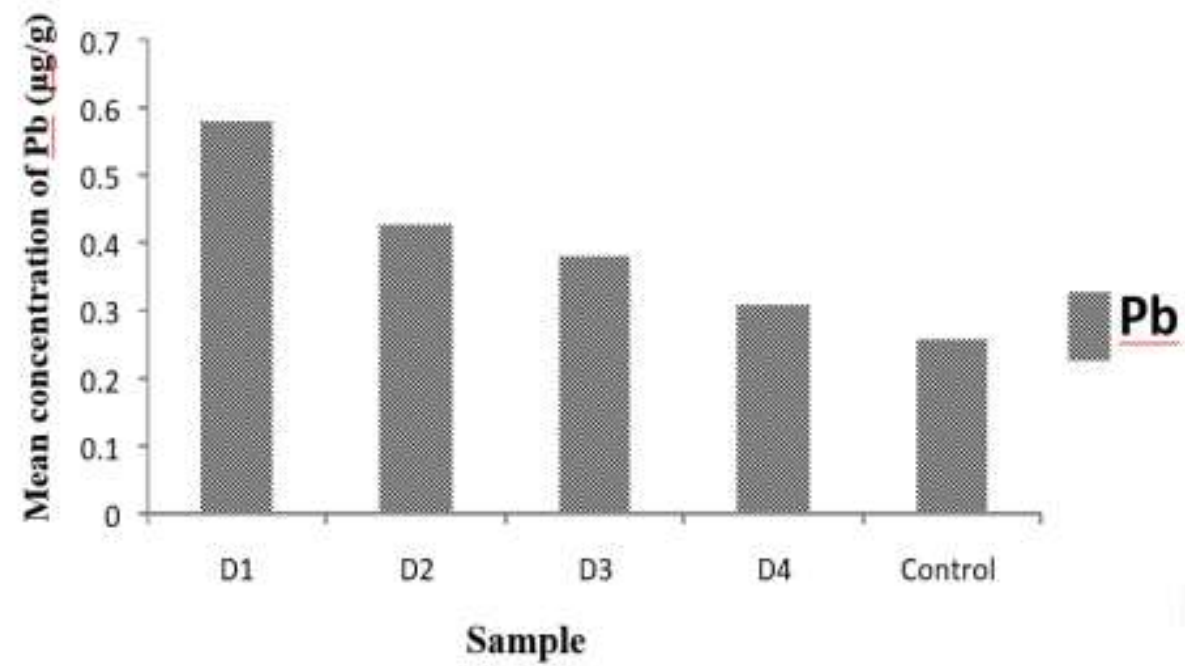

Fig.2: Bar chart representation of the mean values of $\mathrm{Pb}$ in the soil samples.

The mean values of $\mathrm{Pb}$ in the soil samples were statistically significant lead has been reported as a hazardous element and it has the potential for bioaccumulation not only in man but as well in plants and animals ${ }^{24}$. Elemile et $_{\text {al. }}{ }^{23}$ reported a higher range of mean values of $1.93-2.71 \mu \mathrm{g} / \mathrm{g}$ for $\mathrm{Pb}$ in soils around the abattoir in Omu-Aran, Kwara State, than what was obtained for the metal in the studied soil samples.

Chromium: Results of Table 2 shows that the mean values of $\mathrm{Cr}$ in the soil sampling points $\mathrm{D}_{1}, \mathrm{D}_{2}$, $\mathrm{D}_{3}, \mathrm{D}_{4}$ and control were $0.98 \pm 0.19,0.86 \pm 0.10,0.77 \pm 0.15,0.63 \pm 0.09$ and $0.74 \pm 0.10 \mu \mathrm{g} / \mathrm{g}$ respectively. The soil samples had mean values of $\mathrm{Cr}$ in the following decreasing order: $\mathrm{D}_{1}>\mathrm{D}_{2}>\mathrm{D}_{3}>$ control $>\mathrm{D}_{4}$.

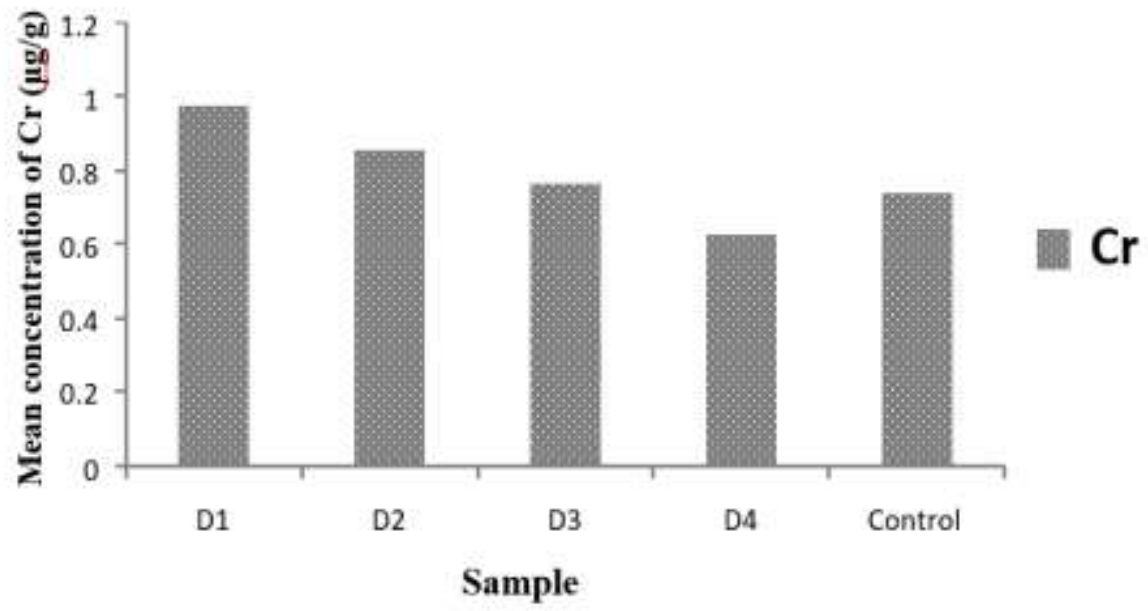

Fig.3: Bar chart representation of the mean values of $\mathrm{Cr}$ in the soil samples.

The values of $\mathrm{Cr}$ in the soil samples were statistically significant but within the WHO recommended limits. The results of this study therefore indicates that the higher levels of $\mathrm{Cr}$ in the control sample 
than in soil sample $\mathrm{D}_{4}$ could be attributed to the higher contamination of $\mathrm{Cr}$ containing wastes at control sites occasioned by the nature of the anthropogenic activities taking place there than at sampling point $\mathrm{D}_{4}$.

Table 3: Contamination/pollution index status of the heavy metals in the soil samples around Nnobi abattoir in Anambra State.

\begin{tabular}{|l|c|c|c|c|c|}
\hline \multicolumn{1}{|c|}{$\begin{array}{c}\text { Sampling } \\
\text { points } \\
\text { Meavy }\end{array}$} & $\mathrm{D}_{1}$ & $\mathrm{D}_{2}$ & $\mathrm{D}_{3}$ & $\mathrm{D}_{4}$ & Control \\
\hline $\mathrm{Cu}$ & 0.28 & 0.24 & 0.23 & 0.21 & 0.19 \\
\hline $\mathrm{Pb}$ & 1.16 & 0.86 & 0.76 & 0.76 & 0.52 \\
\hline $\mathrm{Cr}$ & 0.01 & 0.09 & 0.08 & 0.06 & 0.07 \\
\hline
\end{tabular}

Result of Table 3 shows a moderate contamination of soil sampling point $\mathrm{D}_{1-}{ }_{4}$ with $\mathrm{Cu}$ while at control site there was a slight $\mathrm{Cu}$ - contamination. It was observed in Table 3 that there was a slight pollution of soil sampling point $\mathrm{D}_{1}$ with $\mathrm{Pb}$ as its value was greater than 1 while soil sampling points $\mathrm{D}_{2-4}$, and control had severe $\mathrm{Pb}$ contamination.

The pollution index of sampling point $\mathrm{D}_{1}$ therefore indicates a possible negative effect of $\mathrm{Pb}$ in the soil, plants grown in the soil and the general environment.

Results of Table 3 shows a very slight contamination of soil sampling points $\mathrm{D}_{1-4}$ and control with $\mathrm{Cr}$ and therefore would not pose any negative effect in the studied soil samples, plants grown in it and the general environment.

\section{CONCLUSION}

As the distance of the soil sampling points $\mathrm{D}_{1^{-}}{ }_{4}$ from the abattoir were increased, the soil samples became less acidic. Higher mean values of the studied physicochemical parameters such as total organic carbon, electrical conductivity, suphate, phosphate and organic matter contents were obtained for soil samples $\mathrm{D}_{1-4}$ than in the control. This was attributed to the increased levels of biodegradable wastes at the sampling points close to the abattoir where effluents are discharged that at the other determined sampling point (control).

The mean levels of the physicochemical parameters in the sampling points $\mathrm{D}_{1-4}$ and control were statistically significant. Of all the studied physicochemical parameters in the soil samples, only the mean value of total organic in soil sampling point $\mathrm{D}_{1}$ exceeded the WHO recommended limits.

Except for $\mathrm{Pb}$ in soil sampling point $\mathrm{D}_{1}$, all the other determined heavy metals were present at nontoxic levels in the studied soil samples.

The pollution index of $\mathrm{Pb}$ in soil sampling point $\mathrm{D}_{1}$ suggests $\mathrm{Pb}$ pollution which could pose a serious negative effect in the soil, growths of plants in the soil and the general environment. The study therefore views the abattoir effluent discharge as having a significance influence on the levels of the physicochemical parameters and heavy metals in the soil within the studied environment. The discharge if unchecked and continues unabatedly could pose a serious negative effect on crop yield and a health challenge to man and his environment. 


\section{REFERENCES}

1. E.Dan,K. Fatunla andS. Shraba, Influence of abattoir wastes on soil microbial and physicochemical properties. Research Journal of Chemical studies, 2018,8(12): 1-4.

2. S.T. Ubwra, G.H. Aboo, J.O Ofem, J. Abah and K. Asemave, Effect of activities at the Gboko abattoir a some physical properties and heavy metal levels of surrounding soil. Lud J. Chem,2013, 5:. 47-57.

3. M.R.D. Seaward, The use of Lichens for environmental impact assessment. Symbiosis,2004, 37: 293-305.

4. A.O. Adesewoye, B.O. Opere and S.C.O. Makunde, Microbial content of abattoir waste water and its contaminated soil in Lagos, Nigeria. African J. Biotech, 2006,5. 1963-1968.

5. S.Ezeoha andB. Ugwuishiwu, Status of abattoir waste research in Nigeria. Nigeria Journal of Technology, 2011,30(2): 143-148.

6. D.O.Alorge, Abattoir design, management and effluent disposal in Nigeria. University of Ibadan press Nigeria,1992, 162-168.

7. K.A.Olanike, Unhygienic operation of a city abattoir in South Western Nigeria. Environmental implication. AJEAM / RAGEE,2002, 4:23-28.

8. O.O.Elemile, O.D. Raphael, D.O. Omole, E.O. Oloruntoba, E.O. Ajayi and N.A.Ohwaborua ,Assessment of the impact of abattoir effluent on the quality of ground water in a residential area in Omu-Aran, Nigeria. Environmental Sci,2019, 31:16-22.

9. M.I.Nwachukwu, S.B. Akinde, O.S. Udujih and I.O. Nwachukwu, Effect of abattoir wastes on the population of proteolytic and lipolytic bacteria in a recipient water body (OlammiriRiver). Global Research Journal of Science,2011, 1:40-42.

10. U.J. Chukwu and S.O. Anuchi, Impact of abattoir wastes on the physicochemical properties of soils within Port Harcourt Metropolis. The International Journal of engineering and science, 2016, 5(6): 17-21.

11. O.S. Edori and F. Kpee, Index models assessment of heavy metal pollution in soils within selected abattoirs in Port Harcourt, Rivers State. Eingapore Journal of scientific research,2006, 7: 9-15.

12. M.C.Sharma,S. Baxi, K.K.Sharma, M. Singh and S. Patel, Heavy metal ions levels and related physicochemical parameters in soils in the vicinity of a paper industry location in Nahan area of Himachal Pradesh. Environmental Analytical Technology,2014, 4: 41-49.

13. D.E.Vwioko, G.O.Anoliefo andS.D.Feshemi,Metal concentration in plant tissues of Picinus communis (castor oil) grown in soil contaminated with spent lubricating soil. Journal of Applied Environmental Management, 2006,10: 127-134.

14. G. Tyler, A.U.Balsbey-Rahlsson, G. Bongbosson, E. Baath and L. Tranoik, Water, air and soil pollution. Chand and company limited $6^{\text {th }}$ Edition, 1989,101-122.

15. C.Anyakora, K. Nwaeze, O. Awodele, C.Nwadike, M. Ababi and H. Coker, Concentration of heavy metals in some pharmaceutical effluents in Lagos, Nigeria. Journal of Environmental (chemistry, eco-toxicology, 2011, 3(3): 25-31. 
16. Association of official analytical chemists, Methods of analysis. $15^{\text {th }}$ Edition. Washington D.C., USA.2000, 57-61.

17. E.J.UdoandJ.A.Ogunale, Laboratory manual for the analysis of soil, plants and water sample. $4^{\text {th }}$ Edition, University of Ibadan, Nigeria,2006, 85-88.

18. R.Lacatusu, appraising levels of soil contamination and pollution with heavy metals. European soil Breau Research Report, 2000, 4: 393-402.

19. Orld Health Organization/Food and Agricultural Organization, Guideline on water, soil and food quality and trace elements in human nutrition. Geneva, Switzerland,1996, 193-210.

20. J.C. Akan, S.I. Andu, Z.Mohammed and V.O.Ogugbaja, Assessment of heavy metals, pH, Organic matter and organic catalyst in road side soils in Makurdi metropolis, Benue State, Nigeria. Journal of Environmental Protection,2013, 4:618-628.

21. D.J. Oyedele, M.B. Gasu and O.O. Awotoye, Changes in soil properties and plant uptake of heavy metals on selected municipal solid waste dump site in Ile-Ife, Nigeria. African Journal of Environmental Science and Technology, 2008,3(5): 107-115.

22. G.A. Ayolagha and G.C. Onwughata, Suitability comparison of waste disposal site. $27^{\text {th }}$ proceedings of the annual conference of the soil science of Nigeria in University of Calabar,2001, 4: 136-443.

23. O.O. Elemile, O.D. Raphael, O.D. Omole, O.E. Olawatuyi, E.O. Ajayi, O. Umukoro and M.G. Elemile, Assessment of the impact of abattoir activities on the physiochemical properties of soils within a residential area of Omu-Aran, Nigeria. Materials Science and Engineering,2019, 640:208-214.

24. V.F.Ediene andO.B.Iren, Impact of abattoir effluents on the $\mathrm{pH}$, organic matter, heavy metal levels and microbial composition of surrounding soils in Calabar municipality. Asian Journal of environment and technology,2017, 2(3): 1-10.

* Corresponding Author:Okeke O.,

Plastic Production Section, Scientific Equipment Development Institute, Enugu.

Date of publication on line 30.06.2020 